\title{
Global Financial Crisis and Trade Papers: Topic Analysis Via Latent Dirichlet Allocation Model
}

Global Finansal Kriz ve Ticaret Makaleleri: Gizil Dirichlet Ayrımı Yöntemiyle Başlık Analizi

\section{Halil Şimdi, Büşra Garip*}

Sakarya University, Business School, International Trade and Finance Department, Sakarya, Turkey

\begin{abstract}
We examine the trends in the studies published in international trade journals indexed in Web of Science (WoS) before and after the 2008 Global Financial Crisis (GFC). This study investigates the 5001 abstracts of trade articles starting from the post-millennium period by addressing issues in WoS database trade journals using the Latent Dirichlet Allocation (LDA) topic model. The purpose of the study is to evaluate whether topics and words differ that have been discussed in international trade literature before and after GFC. Mostly, contain topics differ when two periods are compared, although trade agreements and disputes, stock markets, and growth issues are frequently mentioned in both periods. In the post-crisis period, volatility, banks, and firm-specific issues are more popular. It is also among the findings that Asian economies gained importance after GFC. Generally, it has been revealed that the topics and titles in the trade literature can reflect current developments in international economics. Therefore, probably for next years, advances in technology as blockchain, emerging economies -especially China and India - and firm-based micro-scale papers will dominate the trade journals.
\end{abstract}

Keywords: International Trade, Latent Dirichlet Allocation, Topic Modeling, Trends of Trade.
Öz

Çalışmamızda; 2008 Global Finansal Kriz öncesinde ve sonrasında Web of Science'da uluslararası ticaret ile ilgili yayınlanan makalelerdeki trendler ele alınmaktadır. Bu çalışma, milenyum sonrası dönemden başlayarak Web of Science veri tabanında yer alan 5001 uluslararası ticaret makale özetini Gizli Dirichlet Ayrımı başlık analizini kullanarak incelemektedir. Çalışmanın amacı, global finansal kriz öncesi ve sonrası uluslararası ticaret literatüründe tartışılan konuların ve kelimelerin farklılaşıp farklılaşmadığını değerlendirmektir. Çoğunlukla, iki dönem kıyaslandığında konu başlıkları farklılık gösterse de; her iki dönemde de ticaret anlaşmaları ve anlaşmazlıklar, hisse senedi piyasaları ve büyüme sorunları sıklıkla dile getirilmektedir. Kriz sonrası dönemde istikrarsızlık, bankalar ve firmaya özgü konuların daha popüler olduğu görülmektedir Asya ekonomilerinin global finansal krizden sonra önem kazandığı da bulgular arasındadır. Genel olarak ticaret literatüründe yer alan konu ve başlıkların uluslararası ekonomideki güncel gelişmeleri yansıtabildiği ortaya çıkmaktadır. Bu nedenle, muhtemelen önümüzdeki yıllarda gelişmekte olan ekonomiler - özellikle Çin ve Hindistan'da blockchain ve teknolojideki gelişmeler ve firma tabanlı mikro ölçekli makaleler ticaret dergilerine hâkim olacaktır.

Anahtar Kelimeler: Uluslararası Ticaret, Gizil Dirichlet Ayrımı, Başlık Analizi, Ticaret Eğilimleri.

Article Info / Makale Bilgileri:

* Corresponding Author / Sorumlu Yazar: bgarip@sakarya.edu.tr

To cite this article / Atıf için:

Şimdi, H., \& Garip, B. (2021). Global financial crisis and trade papers: Topic analysis via latent dirichlet allocation model. Curr Res Soc Sci, 7(2), 76-94. 


\section{Introduction}

"I think in our global economy; uncertainty is ever increasing. So to accommodate that, we need to build a dynamic economy and dynamic rules that can adapt to changing circumstances" (Myron Scholes). ${ }^{i}$

The story and actors of world trade have changed for years. The journey of world trade has been steadily evolved from the first existence of an Assyrian merchant colony at Kanesh in Cappadocia in 19th century BCE (Newton, 2019) to "multinational corporations," which a term first used by David Lilienthal at a conference at Carnegie Mellon University in 1960 (Chandler and Mazlish 2005) to the globalization popularized by Levitt (1983), one of the editors of Harvard Business Review and to crises like the latest one: COVID-19 Pandemic.

Between the end of World War II and 2008, GFC, a breaking point in global trade, many economic, political, and technological disruptions and changes occurred globally. World Trade Organization (WTO) report these milestones like the birth of the Bretton Woods System in the 1940s, the foundation of the European Union (EU) in the 1950s, the increase of container trade in the 1960s, and the elimination of customs duties within the EU, the oil crisis in the 1970s, rapid technological developments in the 1980s, the establishment of the WTO, the Asian financial crisis in the 1990s and, China's WTO participation, 9/11 Attacks, GFC and technological revolutions in 2000s (World Trade Report 2008). China's WTO participation and GFC can be considered one of the most significant facts affecting the economy from 2000-2009. Notably, after 15-year negotiations in the organization, membership in China has reshaped the world trade since China had disrupted the competition in the mainland for a long time by discriminating against local and foreign firms to support domestic producers. With the membership, China has liberalized its markets, improved the business environment, and reduced input and transaction costs; in that way, global trade has been accelerated for both China and its trading partners (Ianchovichina and Walmsley 2003: 261). Another event that had a more severe impact on international trade was the GFC in 2008. The impact of this crisis spread all over the world via high interdependency among countries. For 2009, world trade decreased by $12.2 \%$ in real or volume terms. The drop in dollar terms is $23 \%$ due to significant price drops, especially for primary commodities such as oil and minerals (Shelburne 2010). Literature has called this period "The Great Trade Collapse" because of its devastating effect on global trade. Although falling commodity prices have severe unfavorable consequences for commodity-dependent exporters, import-dependent developing countries benefited. Thus, the financial crisis has also smoothed the effects of peaking fuel and food prices. Oil prices, which rose by $100 \%$ in $2005-2008$, have declined from a peak of $\$ 147 / \mathrm{barrel}$ to $\$ 40-45 /$ barrel as of March 2009. This has a significant balance of payment implications for oilimporting developing countries, particularly for small developing countries, which have to allocate a much higher share of GDP for fuel imports than large economies (Meyn and Kennan 2009). According to Chor and Manova (2012), two aspects of the GFC are believed to be behind this significant decline in international trade:

- On the producer side, the credit crunch at the height of the crisis resulted in a severe reduction in the availability of external finance, thus curtailing firms' production and export capacities.

- On the consumer side, the gloomy economic outlook led to a slowdown in global demand in general and for imports in particular.

After the 2008 GFC, problems in the world economy have continued. Developments that have affected the global economy and trade between the GFC and 2019 are as follows: The Eurozone debt crisis, which peaked between 2010 and 2012, Brexit triggered by the vote in 2016, Trade War between China and USA started in 2018, and the effect of COVID-19 Pandemic in 2019. 
UNCTAD's annual reports series "Evolution of the International Trading System and Its Trends from a Development Perspective" give significant traces in understanding the trends in international trade between 2008 and 2017. The primary outcomes of the reports are as follows:

- After the GFC, the importance of developing countries in international trade has increased,

- A more protective approach has been observed in investment policies during crisis periods,

- Technology and sustainability issues have become prominent and

- The effects of changes and fluctuations in commodity prices and exchange rates are inevitable.

These circumstances have always affected trade vulnerably. These uncertain and complex cases and trends have caused positive or negative responses such as investments, trade barriers, agreements, integrations, trade costs on the trade side.

Researchers, as well as international organizations, also examine the changes and trends in the economy and international trade in their academic studies and reports. We can observe examining these publications what changes have occurred. It can also be stated that analyzing and predicting the changing structure over the years and periods can provide essential data for stakeholders. They consider how the change and trend are essential for all stakeholders; this study has taken the global financial crisis, a crucial breakdown for international trade, as the middle point. The study, which tries to reveal the trends in the trading world before and after the crisis, also aims to present the trade dynamics between 2000-2019.

Therefore, the study reveals whether trade trends have changed after GFC in articles published in trade journals indexed in WoS between 2000-2019. For this purpose, 5001 papers from 12 different journals have been analyzed by using LDA. Articles have been analyzed on two periods (2000-2009 and 20102019) separated by the GFC, which is accepted as the breaking point for the global trade over these years. This is the first study analyzing the evolution of international trade with the LDA modeling method; it also has observed trends before and after the crisis; therefore, it is thought that this study is original and will contribute to demonstrate the trends in the trade literature.

The structure of this study is organized as follows. Section 2 contains a literature review on related subjects. Section 3 explains the data and methodology. Empirical results are reported in Section 4. Lastly, discussion and suggestions are presented in the conclusion part of the study.

\section{Literature Review}

Academic studies can follow the evaluation in their fields consistently and produce content related to these developments. This effort is significant for both development of science and the quality of future publications. For this aim, some text analysis methods reveal which topics stand out or are less studied. Bibliometric analysis, topic modeling, etc., are seen as prominent text analysis methods in the literature. These text analysis methods are often used in economic and financial studies due to their dynamic structure.

Bibliometric analysis, one of the text analysis methods, is also used to analyze the content of studies in the economy field. By the time the recent studies in the literature are analyzed, it is seen that topics in the economics journals are evaluated by the bibliometric method. Kosnik (2015) investigates the focus of economists in economic journals over the last 50 years to understand which topics gained importance and which ones are now ignored are revealed by text analysis. Claveau and Gingras (2016) examine 
economic journals via bibliometric analysis and reveal specialties in economics. Economics changes through time, and this should be reflected in the structure of its publications. Their study defines expertise and diversity in publications. Klopotan et al. (2018) aim to provide an early warning system for economic and business crises via bibliometric analysis. They investigate the role of early warning systems in predicting and recognizing negative events, especially in the area of business, finances, and the economy. Kosnik (2018) examines the JEL codes to categorize the field of economics. This study aims to find out thematic topics and trends in economic journals via text analysis.

Although there are publications on text analysis in economics, it is challenging to come across academic studies on the evolution of international trade literature from the perspective of studied topics. Generally, the reports of organizations such as the World Bank, WTO, and UNCTAD have been trying to reveal the determinants which shape international trade.

In the framework of academic studies, only one bibliometric analysis was found in the field of international trade. Tian et al. (2018) have examined the relationship between international trade and the environment with bibliometric analysis. They have reviewed journals and articles between 1997 and 2016. They have provided carbon emissions, water consumption, environmental and international trade relations in studies, and obtained the results of interdisciplinary studies. As seen, there are not many studies that reveal the trend of the international trade field in literature. Therefore, this field can be considered an area where new academic studies can be made and contribute to the literature.

\section{Table 1}

Summary of Studies with Bibliometric Analysis

\begin{tabular}{|c|c|c|}
\hline Author/s & Year & Research Aim \\
\hline Kosnik & 2015 & $\begin{array}{c}\text { investigates economic journals over the last } 50 \\
\text { years to understand which topics gained } \\
\text { importance and which ones are now ignored } \\
\text { are revealed }\end{array}$ \\
\hline Claveau ve Gingras & 2016 & $\begin{array}{l}\text { examine economic journals and reveal } \\
\text { specialties in economics. }\end{array}$ \\
\hline Klopotan et al. & 2018 & $\begin{array}{c}\text { provide an early warning system for economic } \\
\text { and business crises }\end{array}$ \\
\hline Kosnik & 2018 & $\begin{array}{l}\text { examines the JEL codes to categorize the field } \\
\text { of economics. }\end{array}$ \\
\hline Tian et al. & 2018 & $\begin{array}{l}\text { examine the relationship between international } \\
\text { trade and the environment with articles }\end{array}$ \\
\hline
\end{tabular}

As mentioned above, another text analysis method used in economy and trade is LDA. It is also referred to as topic modeling and is among the most up-to-date text analysis in this study. This method is used in many different areas and lists the topics of academic studies.

LDA is used as an estimation model, especially in the fields of economics, tourism, finance/banking, marketing, and communication in the literature. Xing and Girolami (2007) in communication; Moro, Cortez, and Rita (2015) and Feuerriegel, Ratku and Neumann (2016) in finance and banking; Zoghbi, Vulić and Moens (2016) and Puranam, Narayan and Kadiyali (2017) in e-commerce and marketing, Guo, Barnes, and Jia (2017) in tourism and finally Ambrosino et al. (2018), Feuerriegel and Pröllochs (2018), Larsen and Thorsrud (2019), Wehrheim (2019) and Edison and Carcel (2020) in economics are some of these studies. 
It can be useful to examine the economy studies in more detail, which we think maybe the closest to international trade studies. Ambrosino et al. (2018) discuss the New Neoclassical Synthesis after the global crisis, and five topics (economists, macroeconomic theories, labor economics, and debt) are defined thanks to LDA. Feuerriegel and Pröllochs (2018) contribute a holistic approach to how stock prices vary. Using the LDA technique, they explain stock reactions and present many topics about it. Larsen and Thorsrud (2019) investigate the Norwegian business newspaper topics in predicting and explaining economic fluctuations. They show many topics such as asset prices, unexpected innovation via LDA. Wehrheim (2019) purposes to demonstrate how topic models can enrich economic historians' methodology via LDA. Edison and Carcel (2020) analyze the U.S Federal Open Market Committee transcripts, discuss which economic modeling was dominant during the GFC, and decide the topics by LDA. The study of Kozlowski et al (2021) investigate directly international trade flows among countries by using LDA to detect the exported products and complexity.

\section{Table 2}

Summary of Studies with Latent Dirichlet Allocation

\begin{tabular}{ccc}
\hline \multicolumn{1}{c}{ Author/s } & Year & Research Aim \\
\hline Ambrosino et al. & 2018 & $\begin{array}{c}\text { discuss the New Neoclassical Synthesis after the } \\
\text { global crisis }\end{array}$ \\
\hline Feuerriegel and Pröllochs & 2018 & $\begin{array}{c}\text { contribute a holistic approach to how stock prices } \\
\text { vary }\end{array}$ \\
\hline Larsen and Thorsrud & 2019 & $\begin{array}{c}\text { investigate the Norwegian business newspaper } \\
\text { topics in predicting and explaining economic } \\
\text { fluctuations }\end{array}$ \\
\hline Wehrheim & 2019 & $\begin{array}{c}\text { purposes to demonstrate how topic models can } \\
\text { enrich economic historians' methodology }\end{array}$ \\
\hline Edison and Carcel & 2020 & $\begin{array}{c}\text { analyze the transcripts of the U.S Federal Open } \\
\text { Market Committee, discuss which economic } \\
\text { modeling was dominant during the GFC }\end{array}$ \\
\hline Kozlowski et al. & 2021 & $\begin{array}{c}\text { Investigates the exported products, complexity and } \\
\text { relations with countries }\end{array}$ \\
\hline
\end{tabular}

Although this method is used to examine different sectors and fields, up to the authors' knowledge, no other study using this method has been found in the field of international trade. Therefore, applying this method to the international trade field demonstrates the originality of the study.

\section{Methodology}

Text mining aims to discover the latent structure of documents and provides a source of information for literature. The model used here was developed by Blei et al. (2003) -LDA- allows auto clustering of text documents with a specified number of clusters referred to as "topic." Modeling assumptions and properties of LDA simultaneously discover the text assigned to the topic (Calvo-Gonzalez et al., 2018). The algorithm of the LDA model is based on a "bag of words" of text and takes co-occurrence of words that appear in similar context and frequency by ignoring grammar or single word order (Ambrosino et al. 2018).

LDA could be applied to almost all subjects of text clustering, from online reviews to open market committee transcripts (Wang et al. 2018; Edison and Carcel 2020). LDA text data analysis consists of two sections: the first model is probabilistic that accepts text as a likelihood function, whereas the 
second part is an approximate inference algorithm due to the unfeasible feature of maximizing likelihood function (Schwarz 2018). The probabilistic model assumes that the probabilistic combination of topics $(T)$ describes each document $(d)$ of total documents $(D)$, and probabilities are defined in a topic vector such as $\psi_{\mathrm{d}}$ of length $T$ that contains each topic $(t) . D \times T$ matrix is the output of LDA as follows:

$\psi=\left(\begin{array}{c}\psi_{1} \\ \vdots \\ \vdots \\ \psi_{D}\end{array}\right)=\left(\begin{array}{ccc}\mathrm{P}\left(\mathrm{t}_{1} \mathrm{I} \mathrm{d}_{1}\right) & \cdots & \mathrm{P}\left(\mathrm{t}_{\mathrm{T}} \mathrm{I} \mathrm{d}_{1}\right) \\ \vdots & \ddots & \vdots \\ \mathrm{P}\left(\mathrm{t}_{1} \mathrm{I} \mathrm{d}_{\mathrm{D}}\right) & \cdots & \mathrm{P}\left(\mathrm{t}_{\mathrm{T}} \mathrm{I} \mathrm{d}_{\mathrm{D}}\right)\end{array}\right)$

The probabilistic distribution of unique words in $D$ defines $t$ with the size of vocabulary $(V)$. Thus, it is possible to monitor a word occurrence probability conditional on a topic. Next, word probability vectors for $t$ are represented in a new vector $\vartheta$ with $V x T$ dimension:

$\vartheta=\left(\vartheta_{1}, \ldots \ldots, \vartheta_{\mathrm{T}}\right)=\left(\begin{array}{ccc}\mathrm{P}\left(\mathrm{w}_{1} \mathrm{It}_{1}\right) & \cdots & \mathrm{P}\left(\mathrm{w}_{1} \mathrm{I} \mathrm{t}_{\mathrm{T}}\right) \\ \vdots & \ddots & \vdots \\ \mathrm{P}\left(\mathrm{w}_{\mathrm{v}} \mathrm{It}_{1}\right) & \cdots & \mathrm{P}\left(\mathrm{w}_{\mathrm{v}} \mathrm{I} \mathrm{t}_{\mathrm{T}}\right)\end{array}\right)$

Vectors determine the observation probability of word from the vocabulary conditional on $t$. As a result of this, $\vartheta_{t}$ vector permits to judge of the content of the topic. However, it does not provide the name of each topic and requires one to evaluate the topic classification.

Text in the whole collection is defined by the following steps under the parameters of $\psi$ and $\vartheta$ :

- $\quad$ Form a word probability distribution $\vartheta \sim \operatorname{Dir}(\beta)$

- For $d$ in the whole text collection:

$\circ \quad$ topic proportions reveal as $\psi_{d} \sim \operatorname{Dir}(\alpha)$

- each of $N_{d}$ words in $d$ draw topic assignment $\left[z_{d, n} \sim\right.$ Mult $\left.\left(\psi_{d}\right)\right]$ and word $w_{d, n}$ from $\left[p\left(w_{d, n} \mathrm{I} z_{d, n}, \vartheta\right)\right]$.

$\beta$ and $\alpha$ refer to hyperparameters in the model. The likelihood function of model parameters under a given probabilistic model is:

$\prod_{d=1}^{D} \mathrm{P}\left(\psi_{d} \mathrm{I} \alpha\right)\left[\prod_{n=1}^{\mathrm{N}_{d}} \sum_{z_{d, n}} P\left(z_{d, n} \mathrm{I} \psi_{d}\right) P\left(w_{d, n} \mathrm{I} \mathrm{z}_{d, n}, \vartheta\right)\right]$

The equation (3) provides the likelihood of the words in documents by observing the topic distribution of $d$ conditional on $\alpha$. On the other hand, adding up a possible topic assignment for words in all documents is required by maximizing likelihood that is not computationally feasible. Therefore, Griffiths and Steyvers (2004) have developed the Gibbs sampling method.

Gibbs sampling method repeatedly draws new samples with a Markov chain in the Monte Carlo algorithm conditional on all data. Gibbs sampler updates topic assignment of words iteratively that conditional on all other words. The Bayesian technique feature of Gibbs sampling requires hyperparameters $(\beta$ and $\alpha$ ). The Gibbs method of LDA divides documents into words (called word tokens), and later randomly, words are randomly assigned with equal probabilities to one topic. The probabilistic model of a word token is determined as follows:

$\mathrm{P}\left(\mathrm{z}_{\mathrm{d}, \mathrm{n}}=\mathrm{t} \mathrm{I} \mathrm{w}_{\mathrm{d}, \mathrm{n}}, \vartheta\right) \propto \mathrm{P}\left(\mathrm{w}_{\mathrm{d}, \mathrm{n}} \mathrm{I}_{\mathrm{d}, \mathrm{n}}=\mathrm{t}, \vartheta\right) \times \mathrm{P}\left(\mathrm{z}_{\mathrm{d}, \mathrm{n}}=\mathrm{t}\right)$

Gibbs sampling takes topic assignment of other tokens to get values approximately for $\mathrm{P}\left(\mathrm{z}_{\mathrm{d}, \mathrm{n}}=\mathrm{t} \mathrm{I}\right.$ $\left.\mathrm{w}_{\mathrm{d}, \mathrm{n}}, \vartheta\right)$ and $\mathrm{P}\left(\mathrm{z}_{\mathrm{d}, \mathrm{n}}=\mathrm{t}\right)$. Besides, the number of identical words for $w_{d, n}$ is assigned to topic split by total 
words of topics gives $\mathrm{P}\left(\mathrm{w}_{\mathrm{d}, \mathrm{n}} \mathrm{I} \mathrm{z}_{\mathrm{d}, \mathrm{n}}=\mathrm{t}, \vartheta\right)$. The application of Gibbs sampling provides to converge local maximum instead of a global probabilistic likelihood model.

\section{Empirical Results}

The dataset of the paper is 5,001 research articles of trade journals stored in WoS from 2000 to $2019^{\text {ii }}$. We determine $\beta$ and $\alpha$ as default ( $\beta=0.1$ and $\alpha=0.25$ ) to set the word and topic probability distribution. Also, we specify 1000 iterations that Gibbs sampling run and 50 iterations that Gibbs sampler ignore between samples. Lastly, our empirical analysis sets the seed as three for the random number generator that guarantees the results' reproducibility.

To observe the impact of the 2008 GFC, the dataset is divided into two parts: 2000-2009 and 20102019. The reason why 2009 is taken as a break is the duration of publication at WoS journals. One of the drawbacks of this study is the unequal distribution of papers in two periods. 911 out of the articles belong to the 2000-2009 period, whereas 4,090 have been published between 2010 and 2019 .

The descriptive statistics of data are shown in Figure 1 that summarizes the number of articles by year for the 2000-2019 period.

\section{Figure 1}

Distribution of Articles of Trade Journals in WoS Database

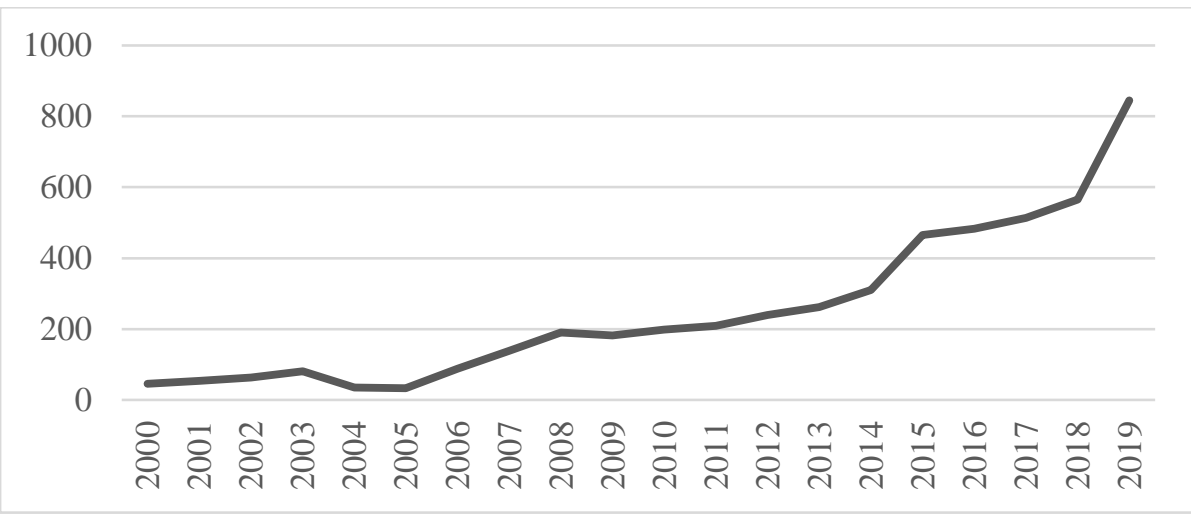

The number of research papers in the field of trade linearly increases except for 2004, 2005, and 2009. Additionally, in 2015 and 2019, published trade papers rose almost 50\%, according to the previous year. The largest share belongs to Emerging Markets Finance and Trade, followed by the Journal of World Trade with $17 \%$. The details (journals and number of papers) of the WoS dataset are as follows:

\section{Table 3}

Details of Papers in WoS Database

\begin{tabular}{lll}
\hline Journals & \# of Papers & $\begin{array}{l}\text { Percent. } \\
(\%)\end{array}$ \\
\hline “Emerging Markets Finance and Trade” & 1955 & 39 \\
\hline “Journal of World Trade” & 852 & 17 \\
\hline “Journal of International Trade and Economic Development” & 558 & 11 \\
\hline “World Trade Review” & 504 & 5 \\
\hline “Journal of Korea Trade” & 269 & 5 \\
\hline
\end{tabular}




\begin{tabular}{lll}
\hline “Journal of World Investment and Trade” & 240 & 5 \\
\hline “Global Trade and Customs Journal” & 195 & 3 \\
\hline “Journal of Trading” & 145 & 3 \\
\hline “Journal of Industry Competition and Trade” & 134 & 1 \\
\hline “Journal of Chinese Economic and Foreign Trade Studies” & 67 & 1 \\
\hline “Journal of International Trade Law and Policy” & 50 & 1 \\
\hline “Foreign Trade Review” & 32 & $\mathbf{1 0 0}$ \\
\hline Total & $\mathbf{5 0 0 1}$ & \\
\hline Source: Auth" & & 1 \\
\hline
\end{tabular}

Source: Authors' calculations.

Table 3 presents that the total share of the first 5 among 12 journals equals $82 \%$. That is, 8 out of 10 papers in Trade Journals are published, one of the - Emerging Markets Finance and Trade, Journal of World Trade, Journal of International Trade and Economic Development, World Trade Review, and Journal of Korea Trade.

We perform the LDA by introducing the text of titles of papers without non-alphanumerical characters separately for the 2000-2009 and 2010-2019 periods. The topic modeling of LDA provides to determine the number of topics, and for our study, it is determined as five. The topics of abstracts and their similarity probabilities for the period between 2000-2009 are listed in appendix (A1). The results display the contents of trade journals' topics between 2000-2009. The first topic of that period is usually regarding the macroeconomic issues (growth, inflation) of countries as Turkey struggled with high inflation and experienced an economic crisis. The second one is related to investment (especially Foreign Direct Investment) and Asian corporates (especially Korean), whereas the third topic contains WTO and legal issues such as agreements and dispute settlements. The subjects of the fourth topic focus on emerging economies and stock markets. Lastly, the trade journals between 2000-2009 contain the goods and services trade and liberalization process.

The topic modeling results of LDA between 2010-2019 are also reported in the appendix (A2). Remarkably, trade literature after the GFC differs from the previous term in terms of topics and word classification in some fields. The LDA results report the most popular five topics of the 2010-2019 period with its words in trade journals of WoS. After the GFC, the papers in trade journals include volatility and crisis. The first topic of that period differs from the 2000-2009 period in terms of European Union legal issues on international trade. The second topic includes financial markets, banks, and Asian firms. In addition to this, China and trade have been used in the trade literature after GFC. Also, the fourth topic covers Korea and China business-based researches. Lastly, the fifth topic demonstrates the impact of GFC on the trade papers by volatility, crisis, and stock markets in emerging economies. Besides, the result of LDA for the 2010-2019 period tends to reveal a shift from a country-specific approach to business-specific.

In the final part of our analysis, we used the word frequency of titles for both periods to explain the differences before and after the GFC in trade literature in terms of titles. Figure 2 depicts the popular title words of trade journals. 


\section{Figure 2}

Word Frequency of Trade Journals' Titles for 2000-2009 and 2010-2019 (\%)

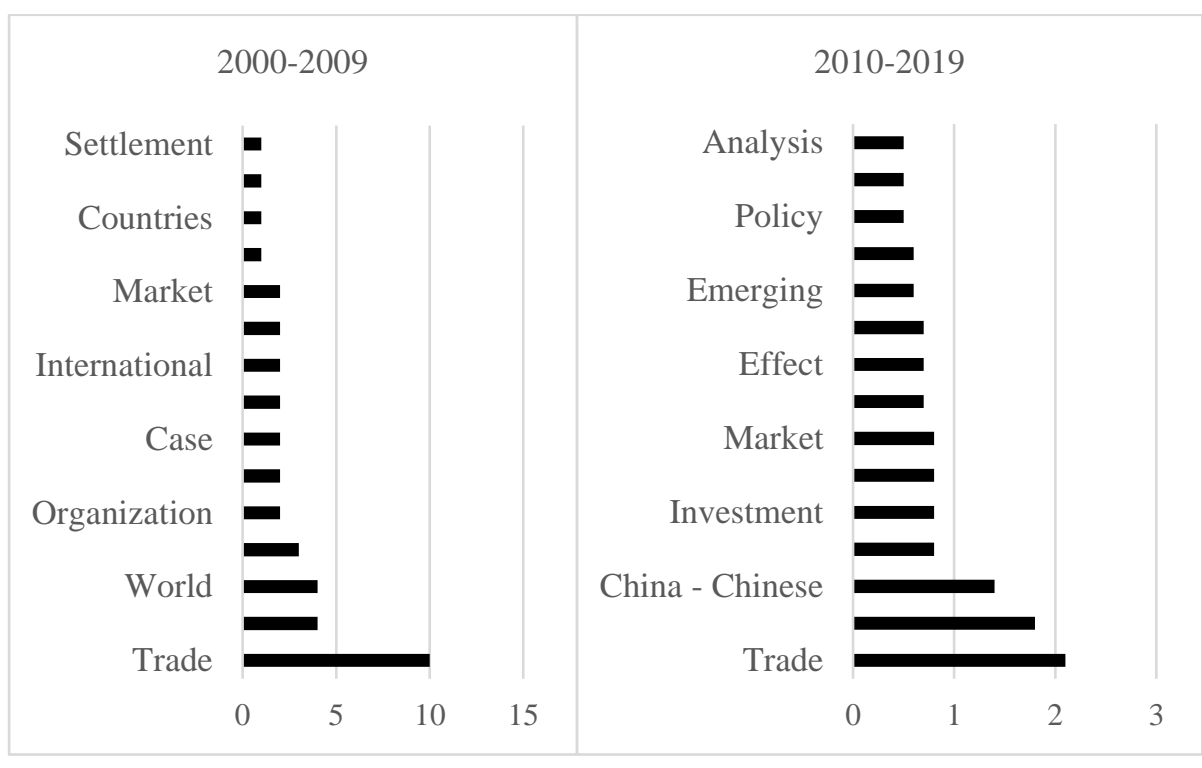

The most popular title word is trade for both terms. However, before GFC, titles of trade journals related to trade agreements, dispute settlements, and trade laws. For 2010-2019, the number of papers is quietly higher than 2000-2009, so the percentages of words are close to each other. Moreover, the participation of China in WTO could affect the title subjects. After the global crisis, topics of trade papers reflect the rise of Asia (China and Korea) and financial markets, according to Figure 2.

\section{Conclusion}

This paper explores the trends of international trade papers' subjects indexed in WoS for 2000-2009 and 2010-2019 to observe the impact of 2008 GFC using the LDA method. The estimation result of LDA is based on a cluster called a topic in the study and word co-occurrence in a similar context.

The study's empirical results show that the topics of the two periods have some differences from each other. The subjects of trade agreements and disputes, stock markets, and growth are popular in both terms. However, after the GFC, the dispute settlements of the EU in the scope of international trade and topics that contain volatility, financial markets, and banks become popular. Furthermore, in the same term, international trade literature evolves from country-specific macro variables (inflation, fiscal policy, etc.) to micro-scale firm-specific variables. The impact of firms' decisions probably becomes more effective than countries' for next years. The findings of the study also suggest that Asian economies (China and Korea) and business-based researches gain more popularity after the GFC. The participation of China in WTO and the rising export trend of Korea contribute to be the subject of international trade studies.

The topics imply that the contents of trade journals focus on more micro-scale subjects in the post-GFC term. In addition to this, legal issues are always popular in the literature. Topics of 2010-2019 add "volatility" to stock markets and emerging economies after the financial crisis. The integration of China into the world trade system by participating in WTO sharply increased the number of papers regarding China in trade journals. Finally, the results reflect that the international trade papers are up to date. The topics and words reveal that the literature keeps up with the current developments in the global economy. Additionally, the number of papers and journals in the field of international trade are indexed in WoS has an increasing trend, especially after 2011. 
The details of topics are summarized in Table 4.

\section{Table 4}

Topics of Trade Journals Before and After GFC

\begin{tabular}{ll}
\hline Topics of 2000-2009 & Topics of 2010-2019 \\
\hline Macroeconomy of Countries & Firms (Especially in Asia) and Financial Markets \\
\hline $\begin{array}{l}\text { Foreign Direct Investment and Corporates in } \\
\text { Asia }\end{array}$ & Korea and China Business Based Researches \\
\hline World Trade Organization, Agreements and & $\begin{array}{l}\text { International Trade Legal Issues and European } \\
\text { Dispute Settlements }\end{array}$ \\
\hline Stock Markets and Emerging States & Volatility and Stock Markets in Emerging \\
\hline Goods and Services Trade and Liberalization & Markets \\
\hline
\end{tabular}

We probably find more technology-oriented, firm, China (probably also India), and EU studies instead of legislation and macroeconomic issues focused papers in the international trade literature for the following years. Moreover, future studies of international trade might include the crypto markets and decentralized market dynamics topics.

\section{Compliance with Ethical Standards}

\section{Ethical approval}

Not applicable.

\section{Author Contributions}

H. Ş. performed in the substantial contribution conception and design, analysis and interpretation of data, statistical analysis; B. G. performed in the acquisition of data, drafting of the manuscript. Both authors have contributed equally to the manuscript for other participations.

\section{Declaration of Conflicting Interests}

The authors declared the study was carried out in the absence of any financial/commercial relationship which could be perceived as a conflict of interest.

\section{References}

Ambrosino, A., Cedrini, M., Davis, J. B., Fiori, S., Guerzoni, M., and Nuccio, M. (2018). What topic modeling could reveal about the evolution of economics. Journal of Economic Methodology, 25(4), 329-348. Doi: 10.1080/1350178X.2018.1529215

Blei, D. M., Ng, A. Y., and Jordan, M. I. (2003). Latent dirichlet allocation. Journal of machine Learning research, 3(Jan), 993-1022.

Bush, G. W., and Glassman, J. K. (2012). The 4\% Solution: Unleashing the Economic Growth America Needs. Currency.

Calvo-González, O., Eizmendi, A., and Reyes, G. (2018). Winners never quit, quitters never grow: Using text mining to measure policy volatility and its link with long-term growth in Latin America. The World Bank.

Chandler, A. D., and Mazlish, B. (Eds.). (2005). Leviathans: Multinational corporations and the new global history. Cambridge University Press.

Chor, D., and Manova, K. (2012). Off the cliff and back? Credit conditions and international trade during the global financial crisis. Journal of international economics, 87(1), 117-133. Doi: 10.1016/j.jinteco.2011.04.001 
Claveau, F., and Gingras, Y. (2016). Macrodynamics of economics: A bibliometric history. History of Political Economy, 48(4), 551-592. Doi: 10.1215/00182702-3687259

Edison, H., and Carcel, H. (2020). Text data analysis using Latent Dirichlet Allocation: an application to FOMC transcripts. Applied Economics Letters, 1-5. Doi: 10.1080/13504851.2020.1730748

Feuerriegel, S., and Pröllochs, N. (2018). Investor reaction to financial disclosures across topics: An application of latent Dirichlet allocation. Decision Sciences. Doi: 10.1111/deci.12346

Feuerriegel, S., Ratku, A., and Neumann, D. (2016, January). Analysis of how underlying topics in financial news affect stock prices using latent dirichlet allocation. In 2016 49th Hawaii International Conference on System Sciences (HICSS), 10721081.

Griffiths, T. L., and Steyvers, M. (2004). Finding scientific topics. Proceedings of the National academy of Sciences, 101(suppl 1), 5228-5235.

Guo, Y., Barnes, S. J., and Jia, Q. (2017). Mining meaning from online ratings and reviews: Tourist satisfaction analysis using latent dirichlet allocation. Tourism Management, 59, 467-483. Doi: 10.1016/j.tourman.2016.09.009

Ianchovichina, E., and Walmsley, T. (2003). The impact of China's WTO accession on East Asia. The World Bank.

Klopotan, I., Zoroja, J., and Meško, M. (2018). Early warning system in business, finance, and economics: Bibliometric and topic analysis. International Journal of Engineering Business Management, 10, 1847979018797013. Doi: $10.1177 / 1847979018797013$

Kosnik, L. R. (2018). A survey of JEL codes: What do they mean and are they used consistently? Journal of Economic Surveys, 32(1), 249-272. Doi: 10.1111/joes.12189

Kosnik, L. R. D. (2015). What have economists been doing for the last 50 years? A text analysis of published academic research from 1960-2010. A Text Analysis of Published Academic Research from, 2010.

Kozlowski, D., Semeshenko, V., \& Molinari, A. (2021). Latent Dirichlet allocation model for world trade analysis. PloS one, 16(2), e245393. Doi: 10.1371/journal.pone.0245393.

Larsen, V. H., and Thorsrud, L. A. (2019). The value of news for economic developments. Journal of Econometrics, 210(1), 203-218. Doi: 10.1016/j.jeconom.2018.11.013

Levitt, T. (1993). The globalization of markets. Readings in international business: a decision approach, 249.

Meyn, M., and Kennan, J. (2009). The implications of the global financial crisis for developing countries' export volumes and values. Overseas Development Institute.

Moro, S., Cortez, P., and Rita, P. (2015). Business intelligence in banking: A literature analysis from 2002 to 2013 using text mining and latent Dirichlet allocation. Expert Systems with Applications, 42(3), 1314-1324. Doi: 10.1016/j.eswa.2014.09.024

Newton, K. (2019). International Relations and World Politics. Scientific e-Resources.

Puranam, D., Narayan, V., and Kadiyali, V. (2017). The effect of calorie posting regulation on consumer opinion: A flexible latent Dirichlet allocation model with informative priors. Marketing Science, 36(5), 726-746. Doi: 10.1287/mksc.2017.1048

Schwarz, C. (2018). ldagibbs: A command for topic modeling in Stata using latent Dirichlet allocation. The Stata Journal, 18(1), 101-117. Doi: 10.1177/1536867X1801800107

Shelburne, R. C. (2010). The global financial crisis and its impact on trade: the world and the european emerging economies. United Nations Economic Commission for Europe-Discussion Papers Series, 2.

Tian, X., Geng, Y., Sarkis, J., and Zhong, S. (2018). Trends and features of embodied flows associated with international trade based on bibliometric analysis. Resources, Conservation and Recycling, 131, 148-157. Doi: 10.1016/j.resconrec.2018.01.002

UNCTAD. (2008-2017). Evolution of the international trading system and its trends from a Development Perspective Report. Available at https://unctad.org/en/Pages/DITC/TNCD/Evolution-of-the-intl-trading-system.aspx.

Wehrheim, L. (2019). Economic history goes digital: topic modeling the Journal of Economic History. Cliometrica, 13(1), 83125. Doi: $10.1007 / \mathrm{s} 11698-018-0171-7$

World Trade Organization. (2008). World Trade Organization Report. Available at https://www.wto.org/english/res_e/booksp_e/anrep_e/wtr08-2b_e.pdf.

Xing, D., and Girolami, M. (2007). Employing Latent Dirichlet allocation for fraud detection in telecommunications. Pattern Recognition Letters, 28(13), 1727-1734. Doi: 10.1016/j.patrec.2007.04.015 
Zoghbi, S., Vulić, I., and Moens, M. F. (2016). Latent Dirichlet allocation for linking user-generated content and e-commerce data. Information Sciences, 367, 573-599. Doi: 10.1016/j.ins.2016.05.047. 


\section{Appendix}

A1. Top 10 Abstracts and Words of Five Topics During 2000-2009

\begin{tabular}{|c|c|}
\hline Topic 1: Macroeconomy of Countries & Prob. \\
\hline $\begin{array}{l}\text { "This paper investigates how various macroeconomic policy shocks in Turkey affect unemployment and } \\
\text { provides evidence on the differential responses of unemployment in selected sectors of economic activity." }\end{array}$ & 0.966 \\
\hline $\begin{array}{l}\text { "The common assumptions that labor income share does not change over time or across countries and that } \\
\text { factor income shares are equal to the elasticity of output with respect to factors have had important } \\
\text { implications for economic theory." }\end{array}$ & 0.962 \\
\hline $\begin{array}{l}\text { "This paper investigates the validity of the Fisher hypothesis using data from thirty-three developed and } \\
\text { developing countries." }\end{array}$ & 0.95 \\
\hline $\begin{array}{l}\text { "We analyze the effects of currency crises on the industrial sectors of Korea, Turkey, and the Czech } \\
\text { Republic." }\end{array}$ & 0.943 \\
\hline $\begin{array}{l}\text { "In this study, we propose an explanation for why labor and capital shares do not seem to have a trend; an } \\
\text { increasing trend in physical capital share is compensated by a decreasing trend in land share." }\end{array}$ & 0.939 \\
\hline $\begin{array}{l}\text { "This paper constructs a quarterly inflation model for Croatia using the general-to-specific approach to } \\
\text { model inflation dynamics." }\end{array}$ & 0.931 \\
\hline $\begin{array}{l}\text { "This paper examines the effect of foreign direct investment FDI on manufacturing exports in four Middle } \\
\text { Eastern and North African MENA." }\end{array}$ & 0.927 \\
\hline $\begin{array}{l}\text { "Using the vector autoregressive methodology, we present estimates of monetary transmission for five new } \\
\text { EU member countries in Central and Eastern Europe with more or less flexible exchange rates." }\end{array}$ & 0.918 \\
\hline $\begin{array}{l}\text { "This paper investigates the effects of foreign trade liberalization of Turkey after } 1980 \text { on the productivity } \\
\text { of industrial sectors." }\end{array}$ & 0.908 \\
\hline $\begin{array}{l}\text { "This study investigates the existence of a J-curve in the Turkish data in the 1987-2000 period by using } \\
\text { quarterly data." }\end{array}$ & 0.907 \\
\hline \multicolumn{2}{|l|}{ Words of Topic 1: Countries, Growth, Trade, Exchange, Economy(ies), Turkey, Capital, Inflation, Labor, Income } \\
\hline Topic 2: Foreign Direct Investment and Corporates in Asia & Prob. \\
\hline $\begin{array}{l}\text { "In this research, we explored the relationship among Web service quality e-customer satisfaction and word- } \\
\text { of-mouth WOM intention." }\end{array}$ & 0.985 \\
\hline $\begin{array}{l}\text { "This paper attempts to examine the impact of Korean firms' strategic choices in entering the Chinese market } \\
\text { on their FDI performance." }\end{array}$ & 0.957 \\
\hline "This paper examines the subsidiary strategy-headquarters control-subsidiary performance relationship." & 0.924 \\
\hline $\begin{array}{l}\text { "In this paper, the multi-dimensional attributes of government export support programs for exhibitors at } \\
\text { international trade fairs ITFs are described, and their effects on sponsored firms' performance are evaluated." }\end{array}$ & 0.923 \\
\hline $\begin{array}{l}\text { "The main purpose of this paper is to verify the DEA (Data Envelopment Analysis) efficiency of } 24 \text { Korean } \\
\text { container terminals for } 3 \text { Years } 2002-2004 \text { using the bootstrap method and to make policy implications to } \\
\text { enhance the efficiency of container terminals." }\end{array}$ & 0.909 \\
\hline $\begin{array}{l}\text { "Using data on } 157 \text { large companies in Poland and Hungary this paper employs Bayesian structural equation } \\
\text { modeling to examine the relations among corporate governance managers' independence front owners in } \\
\text { terms of strategic decision making exporting and performance." }\end{array}$ & 0.908 \\
\hline $\begin{array}{l}\text { "This study emphasizes the role of affiliate programs in creating loyalty thereby helping companies to } \\
\text { maintain their competitive advantage." }\end{array}$ & 0.877 \\
\hline $\begin{array}{l}\text { "This paper examines the effect of corporate governance firm performance and corporate diversification on } \\
\text { the board as well as CEO compensation and its components in the context of an emerging economy-India- } \\
\text { where a managerial market has yet to develop." }\end{array}$ & 0.864 \\
\hline
\end{tabular}


"Using Benford's 1938 law this study documents pervasive evidence that managers of publicly listed Taiwanese firms tend to engage in earnings manipulative activities rounding earnings numbers to achieve key reference points."

"This paper examines the announcement effect of block acquisitions of foreign investors on firm value and the differences in market responses by the type of the purpose of acquisition using the event study methodology."

Words of Topic 2: Firms, Foreign, Performance, Korean, Investment, Market, Corporate, Country, Government, Structure

\begin{tabular}{|c|c|}
\hline Topic 3: World Trade Organization, Agreements and Dispute Settlements & Prob. \\
\hline $\begin{array}{l}\text { "This article discusses the first GATS panel report Mexico-Telecommunications Case DS204 with particular } \\
\text { reference to its interpretation of the meaning of the word "interconnection." }\end{array}$ & 0.968 \\
\hline "This article explores the issue of unilateral measures in the field of international trade." & 0.951 \\
\hline $\begin{array}{l}\text { "This paper examines issues that came before the Appellate Body in two disputes US-Zeroing EC and the } \\
\text { US-Zeroing Japan." }\end{array}$ & 0.951 \\
\hline $\begin{array}{l}\text { "The EC-Biotech dispute exposed the WTO dispute settlement system to a more challenging test than any } \\
\text { previous dispute, this paper discusses how the Panel addressed some of these issues." }\end{array}$ & 0.935 \\
\hline $\begin{array}{l}\text { "The contents and the status of cessation is considerably the same in the law of State responsibility and the } \\
\text { GATT/WTO. However the legitimacy of reparation especially restitution and compensation in the } \\
\text { GATT/WTO is controversial." }\end{array}$ & 0.934 \\
\hline $\begin{array}{l}\text { "Following the creation of the World Trade Organization (WTO) and the application of the WTO's Sanitary } \\
\text { and Phytosanitary Agreement (SPS) Agreement concerns over health and safety have become increasingly } \\
\text { predominant in the international trade regime." }\end{array}$ & 0.933 \\
\hline $\begin{array}{l}\text { "This paper addresses the issues that came before the Appellate Body in the Softwood V dispute concerning } \\
\text { an affirmative antidumping determination by the US Department of Commerce." }\end{array}$ & 0.924 \\
\hline $\begin{array}{l}\text { "This article discusses the Court's recent extension of this well-established case law in the context of an } \\
\text { action for compensation brought by companies subjected to retaliatory measures authorized by the Dispute } \\
\text { Settlement Body (DSB)." }\end{array}$ & 0.922 \\
\hline $\begin{array}{l}\text { "The purpose of this article is to identify two potential difficulties in the application of Article } 5.7 \text { which } \\
\text { appear to follow from certain statements in a de by panels and the Appellate Body in the jurisprudence under } \\
\text { that Article so far." }\end{array}$ & 0.916 \\
\hline $\begin{array}{l}\text { "Since } 1995 \text { World Trade Organization WTO Members have authorized trade retaliation countermeasures } \\
\text { in six disputes and retaliatory measures have been imposed in four of these six disputes." }\end{array}$ & 0.913 \\
\hline
\end{tabular}

Words of Topic 3: Trade, International, Agreement, Measures, Legal, Dispute, World, Rules, Organization, Members

\begin{tabular}{|l|l|}
\hline & \\
\hline Topic 4: Stock Markets and Emerging States & Prob. \\
\hline $\begin{array}{l}\text { "This study examines the volatility of daily stock returns and the volatility of returns during trading and non- } \\
\text { trading hours for securities trading on the Istanbul Stock Exchange." }\end{array}$ & 0.961 \\
\hline $\begin{array}{l}\text { "This paper analyzes the forecast performance of emerging market stock returns using standard } \\
\text { autoregressive moving average ARMA and more elaborated autoregressive conditional heteroskedasticity } \\
\text { ARCH models." }\end{array}$ & 0.95 \\
\hline $\begin{array}{l}\text { "This study assesses the market qualities of alternative price-formation processes for an emerging futures } \\
\text { market-the Taiwan futures market." }\end{array}$ & 0.931 \\
\hline $\begin{array}{l}\text { "This study extends the framework of Brennan 1986 to find the cost-minimizing combination of spot limits } \\
\text { futures limits and margins for stock and index futures in the Taiwan market." }\end{array}$ & 0.93 \\
\hline
\end{tabular}




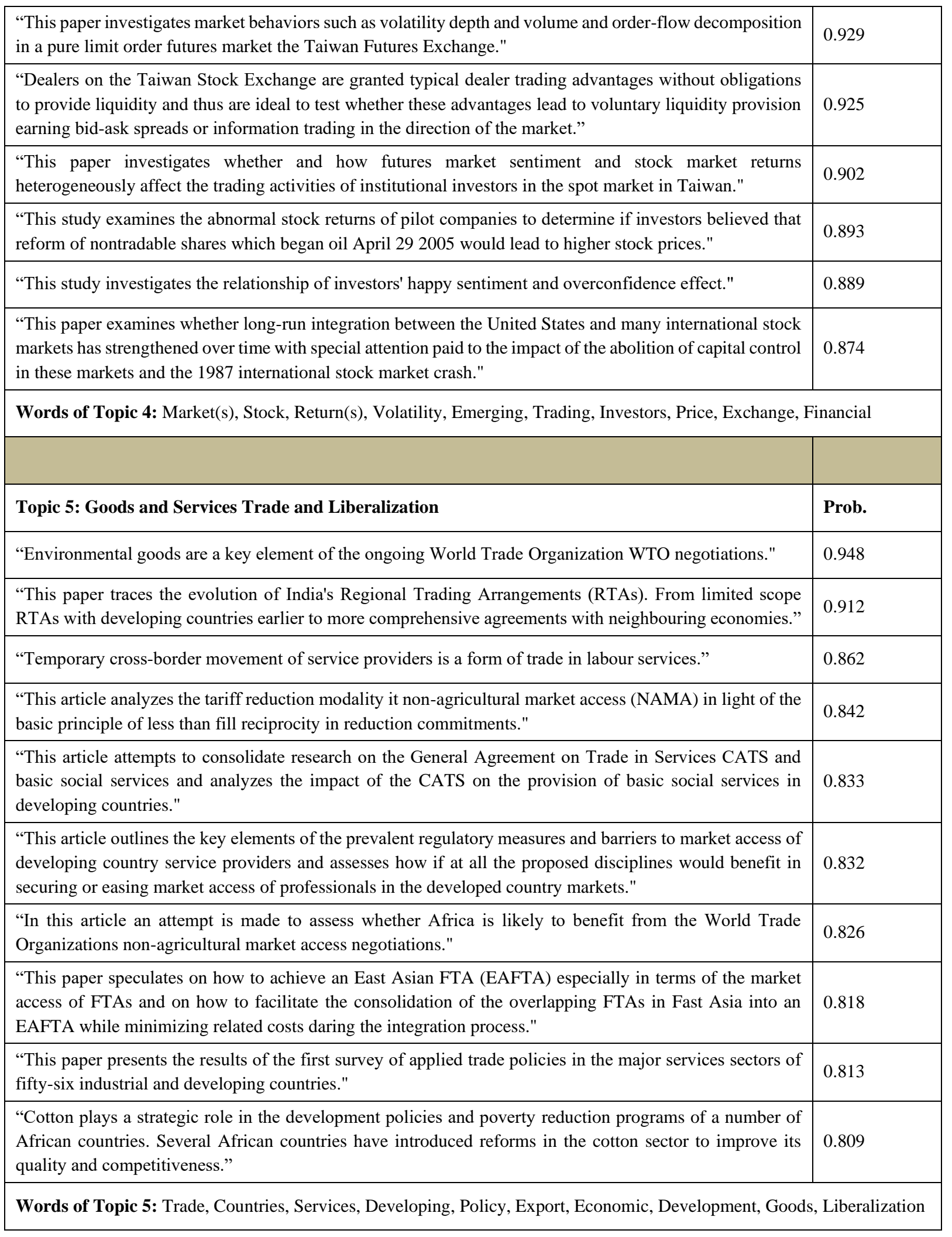




\begin{tabular}{|c|c|}
\hline Topic 1: International Trade Legal Issues and European Union & Prob. \\
\hline $\begin{array}{l}\text { "This article examines three issues arising out of the EU-Canada Comprehensive Economic and } \\
\text { Trade Agreement and puts forward suggestions as to how they may be avoided in future EU } \\
\text { agreements." }\end{array}$ & 0.977 \\
\hline $\begin{array}{l}\text { "With the Lisbon Treaty the European Commission Commission gained a prominent role in } \\
\text { antidumping being empowered to adopt antidumping measures with little interference by the } \\
\text { European Parliament and the Council of the European Union." }\end{array}$ & 0.976 \\
\hline $\begin{array}{l}\text { "This article examines the case law of the Court of Justice of the EU concerning the application of } \\
\text { the new admissibility test to EU customs-related measures between } 2011 \text { and the first half of 2017." }\end{array}$ & 0.976 \\
\hline $\begin{array}{l}\text { "The Trade Facilitation Agreement (TFA) stands in the wake of the Kyoto Convention and other } \\
\text { international Conventions concluded under the auspices of the WTO and the World Customs } \\
\text { Organization (WCO) which contributed to the development of an international customs law." }\end{array}$ & 0.971 \\
\hline $\begin{array}{l}\text { "Opinion 2/15 provides an undisputable exclusive competence to the EU for the inclusion of labour } \\
\text { and environmental standards in EU Free Trade Agreements (FTAs)." }\end{array}$ & 0.965 \\
\hline $\begin{array}{l}\text { "This article analyses the idiosyncrasies of the EU origin marking regime for non-food products and } \\
\text { the latest attempt to reform it In doing so it begins with an overview of the international trade rules } \\
\text { overseeing the entire matter as well as some insights about origin marking schemes in other countries } \\
\text { with particular regard to the United States." }\end{array}$ & 0.963 \\
\hline $\begin{array}{l}\text { "After seven years of negotiations the Comprehensive Economic and Trade Agreement (CETA) was } \\
\text { finally approved and signed on } 30 \text { October 2016." }\end{array}$ & 0.96 \\
\hline $\begin{array}{l}\text { "The Court of Justice of the European Union has long protected the integrity of the Union legal order } \\
\text { from external impact of judicial and norm-creating processes Initially concerned with the harmonious } \\
\text { interpretation and application of Union law the principle has gradually developed into a shield that } \\
\text { protects the judicial prerogatives of the Court against international courts and tribunals." }\end{array}$ & 0.956 \\
\hline $\begin{array}{l}\text { "Increased discussions at the WTO on E-commerce demonstrate a strong interest amongst many } \\
\text { WTO Members to introduce new rules to regulate digital trade." }\end{array}$ & 0.955 \\
\hline $\begin{array}{l}\text { "Could the United States justify its measures on aluminium and steel invoking article XXI b of the } \\
\text { GATT ' is a paper written under the legal framework of the World Trade Organization" }\end{array}$ & 0.955 \\
\hline \multicolumn{2}{|c|}{$\begin{array}{l}\text { Words of Topic 1: Trade, Article, Agreement(s), International, Investment, Dispute, Legal, World, Rules, Measures } \\
\text { System }\end{array}$} \\
\hline Topic 2: Firms (Especially in Asia) and Financial Markets & Prob. \\
\hline $\begin{array}{l}\text { "This study investigates whether the Korean institutional environment harms the monitoring role of } \\
\text { independent venture capital firms while it does not significantly impact corporate venture capital } \\
\text { firms." }\end{array}$ & 0.984 \\
\hline $\begin{array}{l}\text { "This study examines the influence of directors who are politically connected and/or have boardroom } \\
\text { interlocking on private equity placements PEPs in Chinese listed firms." }\end{array}$ & 0.975 \\
\hline $\begin{array}{l}\text { "We investigate the effect of pyramidal ownership and family control on the investment-cash flow } \\
\text { sensitivity of Brazilian firms using financial constraint indexes to classify firms." }\end{array}$ & 0.967 \\
\hline $\begin{array}{l}\text { "The paper aims to examine the determinants of profit performance of financial holding companies } \\
\text { (FHCs) using panel data for the period 2001-9." }\end{array}$ & 0.965 \\
\hline $\begin{array}{l}\text { "The objective of this study was to explore the relationship between promoter ownership and capital } \\
\text { structure of firms' using a sample of Indian publicly listed firms for the period from } 2006 \text { to } 2013 . "\end{array}$ & 0.964 \\
\hline $\begin{array}{l}\text { "This study investigates whether firm donations will attract attention for firms without analyst } \\
\text { coverage." }\end{array}$ & 0.963 \\
\hline
\end{tabular}




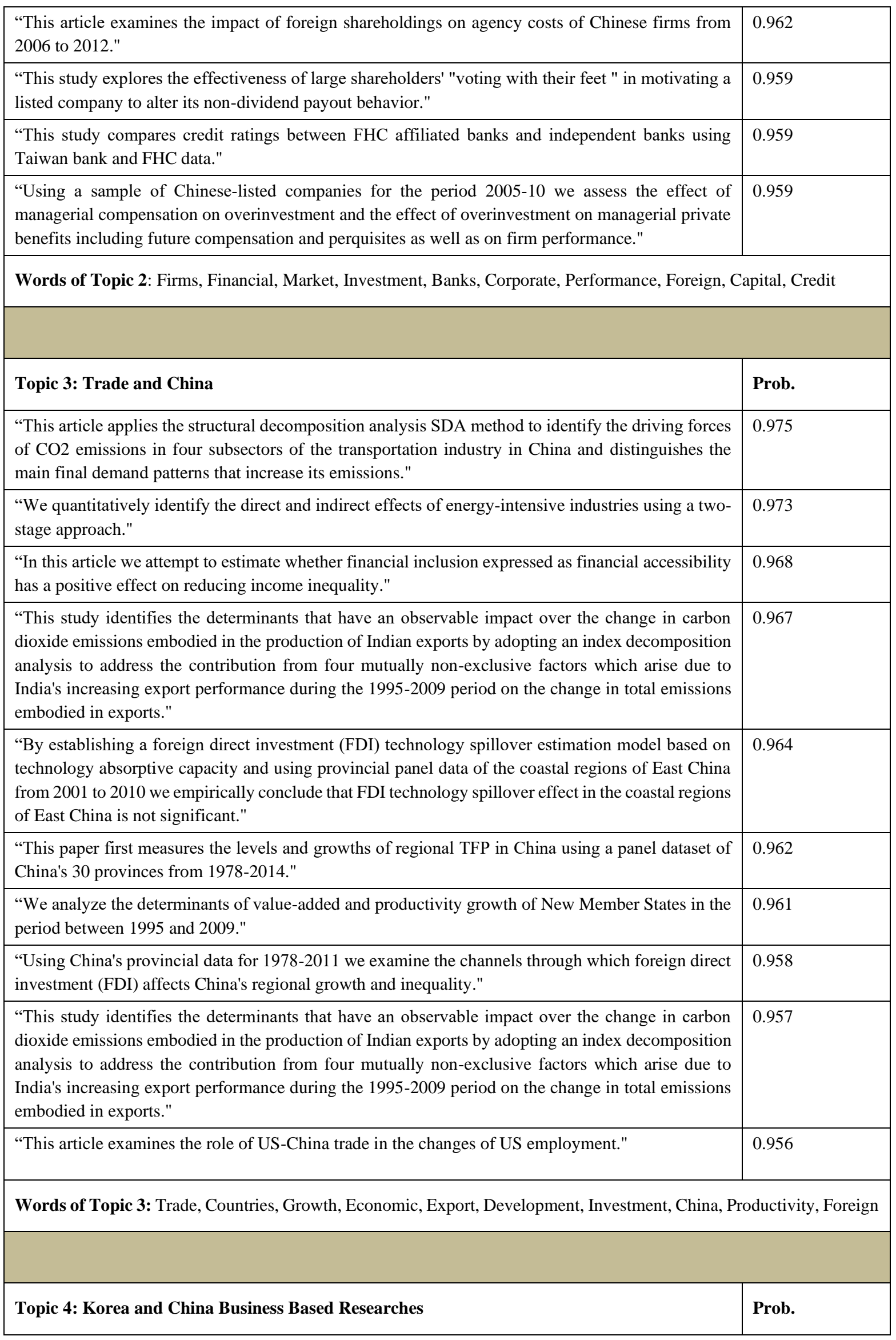




\begin{tabular}{|c|c|}
\hline $\begin{array}{l}\text { "Advocating that affiliation with an export service-provider plays an important role in this } \\
\text { phenomenon we aimed to theoretically explain how export service providers' competences and } \\
\text { relational factors drive small and medium-sized exporters' competitive advantages in the long-run." }\end{array}$ & 0.968 \\
\hline $\begin{array}{l}\text { "The purpose of this paper is to analyze the process of enhancing logistics performances in Korean } \\
\text { exporters' utilizing "third-party logistics" 3PL in area of delivery service to overseas buyers." }\end{array}$ & 0.958 \\
\hline $\begin{array}{l}\text { "The purpose of the study is to examine the factors that motivate importers to be committed to the } \\
\text { relationship with their overseas exporters." }\end{array}$ & 0.952 \\
\hline $\begin{array}{l}\text { "The global trade environment demands a safe and fast trade clearance system for the sake of trade } \\
\text { facilitation and customer satisfaction." }\end{array}$ & 0.948 \\
\hline $\begin{array}{l}\text { "The effects of E-S-QUAL (electronic service quality) and CNFU (consumers' need for uniqueness) } \\
\text { on attitude are examined with data collected from Korean consumers who have cross-border online } \\
\text { purchasing experience." }\end{array}$ & 0.944 \\
\hline $\begin{array}{l}\text { "This study explores the impacts of psychological factors on entrepreneurs' preferences for causal } \\
\text { and effectual decision-making logics." }\end{array}$ & 0.917 \\
\hline $\begin{array}{l}\text { "This paper tried to identify the impact of electronic word of mouth (eWOM) on purchase intention } \\
\text { (PI) of Korean-brand cars in the context of Russian consumers taking into consideration the } \\
\text { credibility quality and quantity of eWOM while also considering the mediation effects of brand image } \\
\text { (BI) and perceived quality (PQ)." }\end{array}$ & 0.917 \\
\hline $\begin{array}{l}\text { "Based on a survey of } 317 \text { born-global SMEs this study used characteristics of organizations } \\
\text { environments and technologies as determinants affecting their international outcomes." }\end{array}$ & 0.913 \\
\hline $\begin{array}{l}\text { "This study investigates the three dimensions of trust belief on policyholders' purchase intentions in } \\
\text { a third-party online insurance platform." }\end{array}$ & 0.907 \\
\hline $\begin{array}{l}\text { "With this background this research performed quantitative analysis after collecting and utilizing log } \\
\text { data of } 346 \text { companies and classing the firms into } 6 \text { representative sectors." }\end{array}$ & 0.903 \\
\hline \multicolumn{2}{|c|}{$\begin{array}{l}\text { Words of Topic 4: Performance, Korea (Korean), China (Chinese), Business, Industry, Management, Network, Market } \\
\text { Export, Innovation }\end{array}$} \\
\hline Topic 5: Volatility and Stock Markets in Emerging Markets & Prob. \\
\hline $\begin{array}{l}\text { "This study presents empirical evidence related to futures pricing for the SGX FTSE Xinhua China } \\
\text { A50 and HKEx H-share index futures markets." }\end{array}$ & 0.981 \\
\hline $\begin{array}{l}\text { "This work provides new evidence of Asia-Pacific stock market integration by incorporating the } \\
\text { regime changes of each stock market through the smooth transition autoregressive STAR model." }\end{array}$ & 0.978 \\
\hline $\begin{array}{l}\text { "This article analyzes the economic and financial sources of fluctuations among the US federal funds } \\
\text { rates the US economic policy uncertainty and the indices of the US, European, Asian, and Islamic } \\
\text { stock markets." }\end{array}$ & 0.974 \\
\hline $\begin{array}{l}\text { "This paper investigates the interaction between crude oil prices and individual investor sentiment } \\
\text { with the Hiemstra and Jones (HJ) test the Diks and Panchenko (DP) test the time-varying parameter } \\
\text { structural vector autoregression (TVP-SVAR) model and the nonlinear autoregressive distributed } \\
\text { lags (NARDL) model." }\end{array}$ & 0.973 \\
\hline $\begin{array}{l}\text { "This article investigates the asymmetric and long memory volatility properties and dynamic } \\
\text { conditional correlations (DCCs) between Brazilian, Russian, Indian, Chinese, and South African } \\
\text { (BRICS) stock markets and commodity gold and oil futures markets using the trivariate DCC- } \\
\text { fractionally integrated asymmetric power autoregressive conditional heteroskedasticity } \\
\text { (FIAPARCH) model." }\end{array}$ & 0.973 \\
\hline $\begin{array}{l}\text { "The authors explore the sources of the resilience of the Turkish economy to the global financial } \\
\text { crisis of 2008." }\end{array}$ & 0.972 \\
\hline
\end{tabular}


"We empirically investigate the recent history of currency crises stress periods and the factors influencing their likelihood in India."

0.971

"This study examines the financial integration of large- and small-cap stocks in twenty-three emerging markets to determine their degree of market integration with the world market."

"This paper studies the risk-return trade-off in some of the main emerging stock markets in the world"

"This is the first study to examine the intraday price discovery and volatility transmission processes between the Singapore Exchange and the China Financial Futures Exchange Using one-and fiveminute high-frequency data from May to November 2011."

Words of Topic 5: Market(s), Stock, Exchange, Price(s), Financial, Volatility, Policy, Emerging, Crisis, Shocks

\section{Notes}

${ }^{\text {i }}$ Bush, G. W., \& Glassman, J. K. (2012). The 4\% Solution: Unleashing the Economic Growth America Needs. Currency.
ii Trade journals mean that containing the word "Trade" in the journal title. 